\section{Landsat TM imagery and NDVI differencing to detect vegetation change: assessing natural forest expansion in Basilicata, southern Italy}

\author{
Giuseppe Mancino, Angelo Nolè, Francesco Ripullone, Agostino Ferrara
}

The NDVI (Normalized Difference Vegetation Index) differencing method using Landsat Thematic Mapping images was implemented to assess natural expansion of forests in the Basilicata region (southern Italy) for the period 1984 through 2010. Two Landsat TM (Thematic Mapper) images (1984-2010) were georeferenced and geographically corrected using the first order polynomial transformation, and the nearest neighbour method for resampling. The images were radiometrically corrected using the dark object subtraction model. The pre-processed Landsat TM images were used to calculate NDVI, and subsequently for NDVI differencing. Finally, a threshold for vegetation change detection was identified by visual analysis of Landsat TM RGB band composition, and ratios and visual comparison of digital aerial orthophotos. The methodology was validated using ground-truth observations over the study area. The applied method showed $\mathbf{9 1 . 8 \%}$ accuracy in detection of natural forest expansion. During the examined period, total regional forest cover increased by 19.7\% (70 $154 \mathrm{ha}$ ), consistent with National Forest Inventory data (19842005). The observed forest expansion was also examined in relationship with landscape physical characteristics and distribution of vegetation types in the Basilicata region. Surprisingly, considerable forest expansion also occurred on degraded soils in drought-prone Mediterranean areas.

Keywords: NDVI Differencing, Landsat TM, Detection Change, Natural Forest Expansion

\begin{abstract}
Introduction
Assessment of natural forest expansion represents a crucial issue to elucidate several processes, including biogeochemical cycles, atmospheric composition related to climate change, and forest carbon uptake, as well as socio-economic processes and issues. Anthropogenic and naturally induced land cover changes affect spatial and temporal distribution and availability of environmental resources, and alter ecosystem composition and productivity. Globally, these processes can be considered the primary catalysts for change in biogeochemical cycling, atmospheric composition, and climate (Pielke
\end{abstract}

2005, Metz et al. 2007, Turner et al. 2007). Forest land-use and land-cover change (LULCC) were recognised as key issues in greenhouse gas removal/emission processes as specified by the Good Practices Guidance for Land Use, Land Use Change, and Forestry (GPG-LULUCF) during the Intergovernmental Panel on Climate Change (IPCC) established at the Kyoto Protocol (Penman et al. 2003). Observation and assessment of forest cover changes are crucial to elucidate the complexities inherent in feedback processes between forest distribution and human activities in sustainable forest development, natural resource management, biodi-

School of Agricultural, Forestry, Food and Environmental Sciences, University of Basilicata, v. N. Sauro 10, Potenza (Italy)

@ Angelo Nolè (nole@unibas.it)

Received: Nov 20, 2012 - Accepted: Sep 29, 2013

Citation: Mancino G, Nolè A, Ripullone F, Ferrara A, 2014. Landsat TM imagery and NDVI differencing to detect vegetation change: assessing natural forest expansion in Basilicata, southern Italy. iForest 7: 75-84 [online 2013-12-18] URL: http://www.sisef.it/iforest/ contents/?id=ifor0909-007

Communicated by: Raffaele Lafortezza versity conservation, ecosystem functioning, and biogeochemical cycling (IPCC 2007). In Mediterranean regions, natural forest expansion is primarily related to the abandonment of agricultural practices and cattle-raising in marginal areas representing the principal change in Italy's Mediterranean rural landscape over the past five decades (Piussi 2005). These processes generally vary in terms of the vegetation successional series and time scale, however the expansion dynamics are shared, beginning with an initial phase of spontaneous shrub dominance, followed by tree colonisation (Biondi et al. 2006).

In recent decades, satellite-based high-resolution observations with multispectral scanners provided the scientific community with consistent data to implement detailed thematic mapping for local and regional scale land classification (Friedl et al. 2002, 2010, Lu \& Weng 2007, Giri 2012). The near infrared wavebands on the Landsat Thematic Mapper (TM) facilitates advanced land classification analyses based on differences in spectral reflectance of different land cover types. In particular, specific foliar reflectance, pigment absorptions, and foliar moisture wavelength ranges represent the basis of vegetation class analyses. Furthermore, the availability of such land cover data at different spatial and temporal scales promotes the development and implementation of vegetation change detection techniques, which furthers our understanding on vegetation and ecosystem dynamics (Cohen \& Fiorella 1998, Coppin et al. 2004, Lu et al. 2004, Martinez \& Gilabert 2009).

In forest ecosystems, land cover change dynamic detection based on visual and statistical approaches represents a challenge to the scientific community due to the difficulties in remotely sensed image acquisition errors as remnant geometric errors, atmospheric scatter, and cloud effects. Other main sources of error are related to physical variability in land characteristics, including topography, vegetation types, and phenology (Shoshany 2000, Roy et al. 2002). In particular, Verbesselt et al. (2010) proposed categorising vegetation changes at the ecosystem level under different classes based on a temporal scale (seasonal, gradual, and abrupt changes), and on the factors driving change, such as seasonal environmental constraints, inter-annual climate variability, land management, and disturbances (deforestation, fires, and floods). In many cases, land cover changes in highly fragmented forest areas can be mismatched with inter-annual variability due to plant phenology or seasonal productivity patterns related to climate variability (De Beurs \& Henebry 2005). The comparison between the time-series of remotely sensed imagery might include a combination 
Fig. 1 - Study area: Basilicata Region, southern Italy.

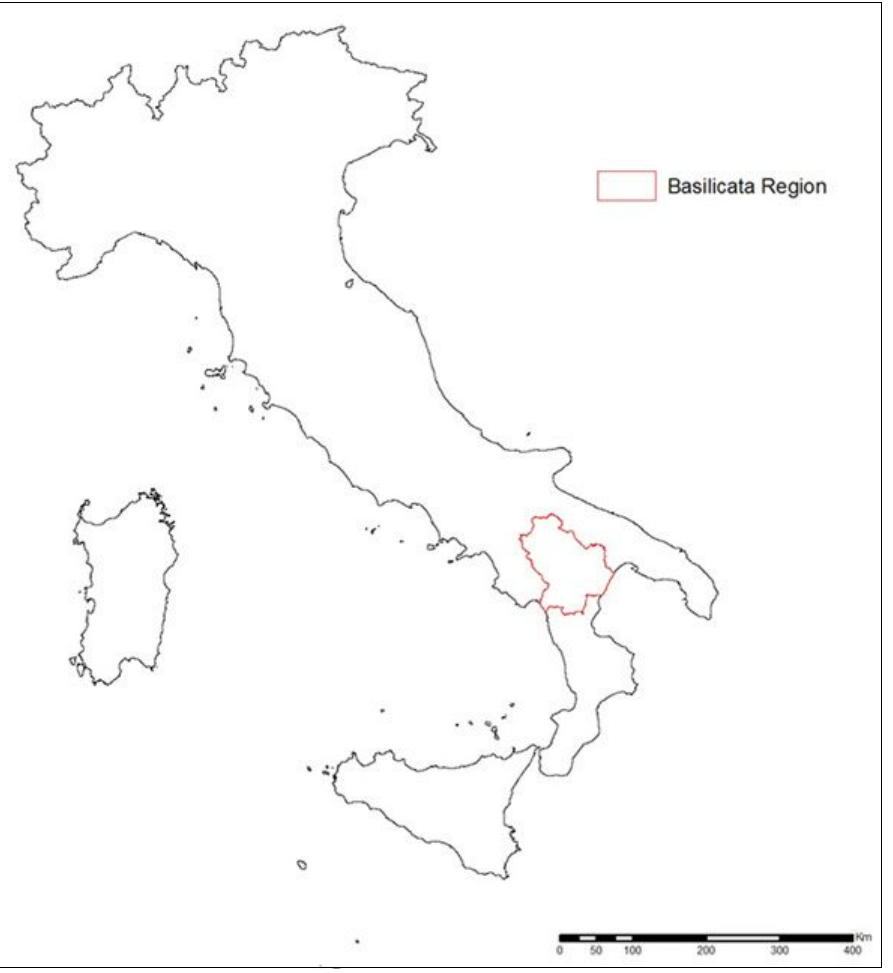

of seasonal variability and abrupt changes; therefore a long-term dataset represents the fundamental choice for change detection (Setiawan \& Yoshino 2012). Several proposed vegetation change detection methods are based on the same image pre-processing to create a time-series dataset, requiring a geometric and radiometric image correction Coppin \& Bauer (1996) and Milne (1988) reported the main methodological approaches for vegetation change detection can be distributed into four broad categories: (i) linear procedures (difference and ratio images); (ii) classification routines (post-classification change, spectral pattern change); (iii) transformed data sets (vegetation indexes, principal components analysis-PCAs); and (iv) others, such as regression analysis, knowledge-based expert systems, or neural
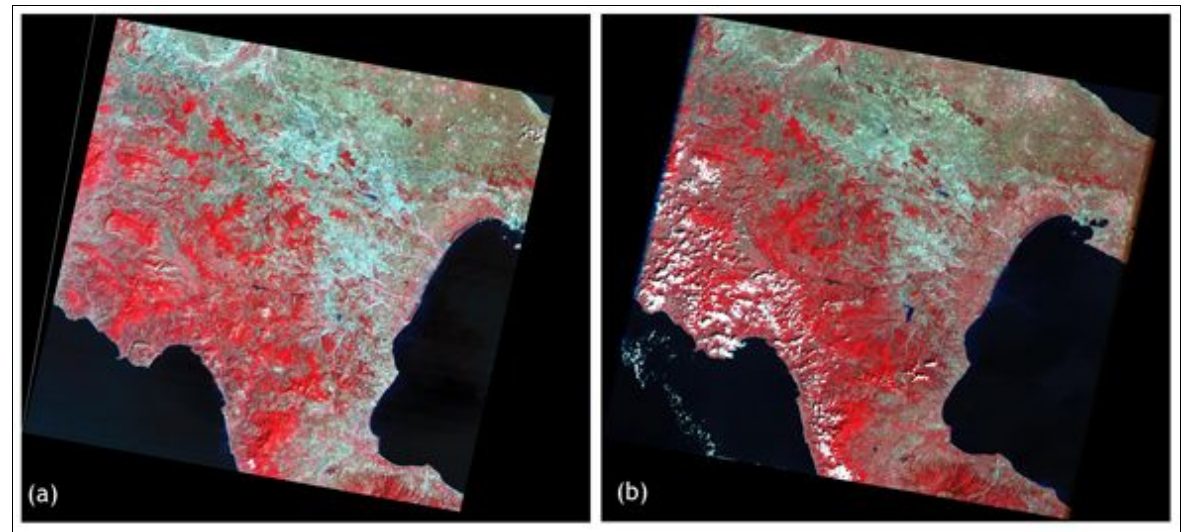

Fig. 2 - Landsat TM images (Path 188, Row 32) Band composition 4-3-2; image dates: (a) 08 September 1984; and (b) 16 September 2010. from other surfaces based on green vegetation chlorophyll absorption of red light for photosynthesis, and reflection of NIR wavelengths (Tucker 1979). The NDVI differencing technique was widely applied for both human-induced and natural forest cover change detection as land cover conversion, forest harvesting, revegetation, or afforestation that includes natural forest expansion and human-induced landscape restoration (Lyon et al. 1998, Wilson \& Sader 2002, Sader et al. 2003, Lunetta et al. 2002, 2006, Nabuurs et al. 2007, Podeh et al. 2009). In addition to the standardized techniques for pre-processing and differencing images, the most important step for vegetation change detection analysis is discrimination between real changes and seasonal or inter-annual variability, represented by a threshold between these factors, which is generally determined by applying the standard deviation (SD) from the NDVI differencing image (Hayes \& Sader 2001, Coppin et al. 2004, Desclée et al. 2006, Sepehry \& Liu 2006, Pu et al. 2008).

In the present study, we propose a vegetation change detection analysis based on the NDVI differencing technique to assess forest cover changes related to natural forest expansion for the Basilicata region (southern Italy) from 1984 through 2010. The objectives were as follows: (i) to develop a procedure for pre-processing Landsat TM imagery, NDVI differencing, and identification of a threshold for vegetation change detection; and (ii) to determine primary patterns of the natural forest expansion in Mediterranean environments.

\section{Material and methods}

\section{Study area}

The study area represents the Basilicata region in southern Italy (Fig. 1). The regional territory is dominated by a mountainous area to the west, flanked by the Apennine Mountain range, while the east is comprised of low hills and wide valleys grading into flat plains on the south coast, along the Ionian Sea. The topography is consistent with climate characteristics, annual temperatures, and precipitation patterns indicating a Mediterranean humid type in the Apennine Mountain range, and a Mediterranean dry climate type in the hilly and flat areas. The annual rainfall average recorded at Senise and Terranova di Pollino was respectively $730 \mathrm{~mm}$, and from $416 \mathrm{~mm}$ to $1211 \mathrm{~mm}$, and annual temperatures ranged from a mean minimum temperature of $10{ }^{\circ} \mathrm{C}$ to mean maximum temperatures of $20-24{ }^{\circ} \mathrm{C}$ (Cantore et al. 1987, Fiorenzo et al. 2008).

Forests cover $35.6 \%$ (355 367 ha) of the total regional surface (999 400 ha - ISTAT 2001). The Regional Forest Atlas (Costantini et al. 2006) reported deciduous oak forests 
representing $51.8 \%$ of the forest cover, while other forest types were generally characterized by lower extensions, including Beech forest $(8.4 \%)$, Mediterranean Macchia (7.9\%), shrublands $(6.9 \%)$, and other deciduous broad-leaved forests $(5.5 \%)$. The remaining $19.5 \%$ were comprised of evergreen broadleaved forests, Mediterranean pine forests, Chestnut stands, hygrophilous forest, and Garrigue. Coppices represented $51.6 \%$ of the total managed forests, while high stands represented the remnant.

\section{Image pre-processing}

Two Landsat TM cloud free images (path 188 , row 32) with $30 \times 30 \mathrm{~m}$ spatial resolution were analysed (acquiring image periods: 8 September 1984 and 16 September 2010 Fig. 2). Image registration and/or rectification are required to facilitate image conformity to another image, and involves georeferencing if the reference image is already rectified to a particular map projection. Landsat TM 2010 was projected using 26 ground control points (GCPs) to the Universal Transverse Mercator (UTM) projection System (zone number: $33 \mathrm{~N}$; reference datum: WGS84). The first order polynomial transformation model and nearest neighbor method for resampling were used for geographical correction of the two images, with a Root Mean Square (RMS) error of 0.5 pixels. Subsequently, the TM 1984 image was geo-coded to the TM 2010 image by the "map-to-map" method, and resampled with a first-order polynomial nearest neighbor algorithm using 12 GCPs for the registration process. The Root Mean Square Error (RMSE) for the map registration process was 0.5 .

The two images were subsequently clipped to the final study area, and radiometrically corrected using the dark object subtraction model (Chavez 1996), a widely applied methodology considered one of the best approaches for the radiometric correction in change detection analysis (Song et al. 2001, Lu et al. 2002, Hu et al. 2004, Schroeder et al. 2006, Mancino et al. 2009, Wang \& Xu 2010). The reliability of the radiometric correction was confirmed using an inter-calibration algorithm between the NDVI images over a test area of the study site. Among the numerous radiometric normalization approaches specific to Landsat data (Elvidge et al. 1995, Jensen 1996, Yuan \& Elvidge 1996, Yang \& Lo 2000, Callahan 2001, Over et al. 2003, Mateos et al. 2010), we selected the intercalibration algorithm, defined as no-change (NC) regression normalization, which has already been applied over areas characterized by very complex landscape patterns (Simoniello et al. 2008). Comparisons of results between the dark object subtraction model and the inter-calibration algorithm of $\mathrm{NC} \mathrm{re-}$ gression normalization showed no significant differences in change detection over forest areas between the two methods. Crossclassification between the two images exhibited a $2 \%$ difference for analysis of all land use changes, which was reduced to less than $1 \%$ for the assessment of only forest land use changes.

\section{NDVI differencing}

Change detection in land use alterations during the analysis period (1984-2010) was analyzed using the NDVI differencing technique following Singh (1989). First, we calculated NDVI following the general normalized difference between Band TM4 (near infrared - NIR) and band TM3 (visible red RED) from the two Landsat TM pre-processed images (1984 and 2010 - eqn. 1):

$$
N D V I=\frac{T M 4-T M 3}{T M 4+T M 3}
$$

The resulting images were subtracted to assess the $\triangle$ NDVI image with positive (NDVI increase) and negative (NDVI decrease) changes on a $30 \times 30 \mathrm{~m}$ pixel resolution (eqn. 2):

$$
\Delta N D V I=N D V I_{2010}-N D V_{1984}
$$

The NDVI difference image was also tested to determine its goodness-of-fit to a normal distribution. Mean, mode, median, standard deviation, and specific statistical indexes
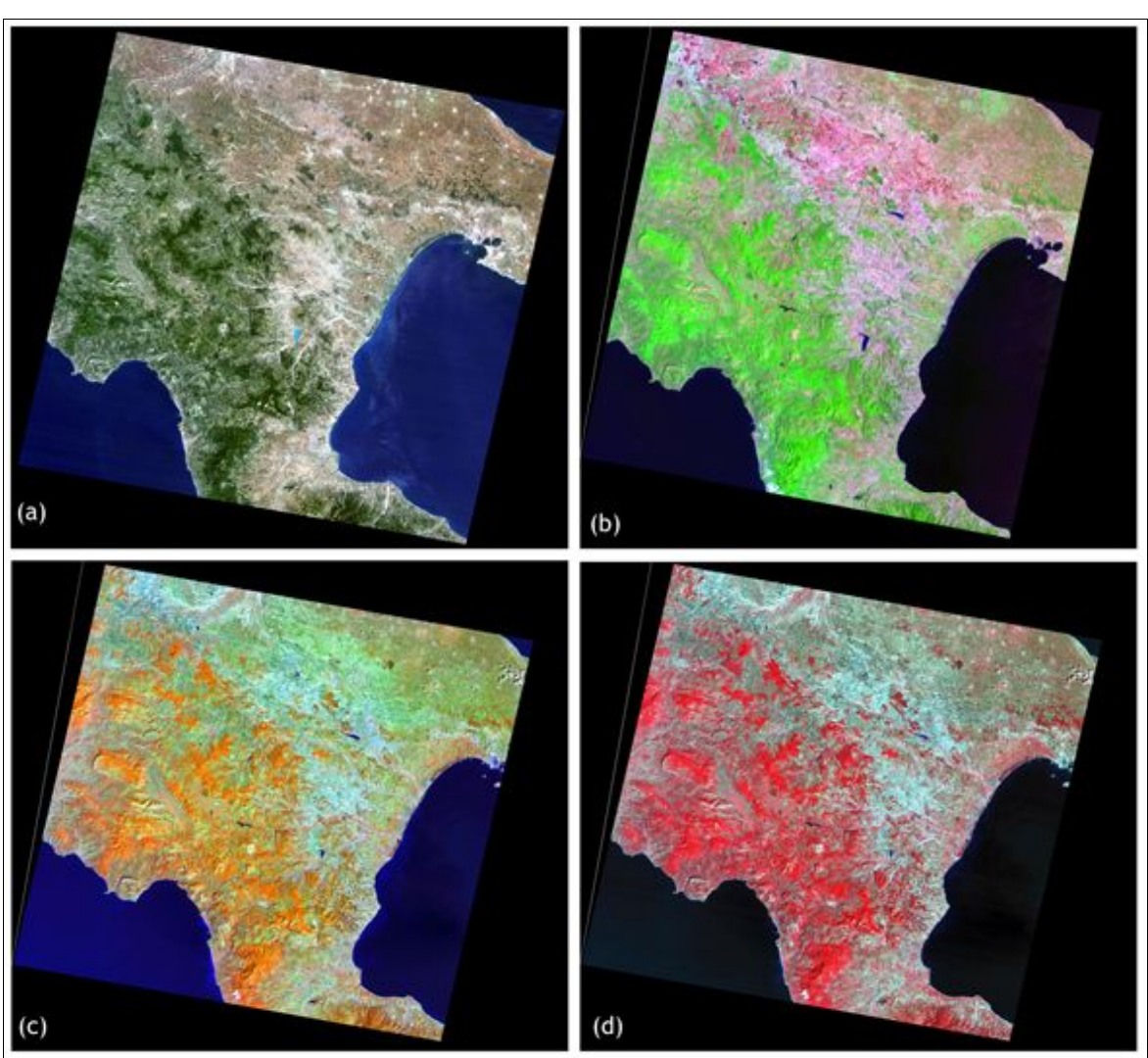

Fig. 3 - Landsat TM band composition. (a) TM3-2-1; (b) TM7-4-2; (c) TM4-5-1; (d) TM4$3-2$.

were generated, including skewness (Kendall \& Stuart 1969, Groeneveld \& Meeden 1984), and kurtosis (Balanda \& MacGillivray 1988), and Kolgomorov-Smirnov nonparametric tests (Lilliefors 1967, Justel et al. 1997) were conducted.

The difference image $\triangle$ NDVI was then reclassified using a threshold value calculated as $\mu \pm n \cdot \sigma$; where $\mu$ represents the $\Delta \mathrm{NDVI}$ pixels digital number mean, and $\sigma$ the standard deviation. The threshold identifies three ranges in the normal distribution: (a) the left tail ( $\Delta$ NDVI $<\mu-n \cdot \sigma)$; (b) the right tail ( $\Delta$ NDVI $>\mu+n \cdot \sigma)$; and (c) the central region of the normal distribution $(\mu-n \cdot \sigma<$ $\Delta$ NDVI $<\mu+n \cdot \sigma)$. Pixels within the two tails of the distribution are characterized by significant vegetation changes, while pixels in the central region represent no change. The $n$ factor defines the range of dispersion around the mean. This study considered only the positive variation in forest cover defined as the area of probable natural forest expansion.

Threshold identification for detection of vegetation changes represents a key issue in the NDVI differencing method. The standard deviation $(\sigma)$ is one of the most widely applied threshold identification approaches for different natural environments based on different remotely sensed imagery (Singh 1989, Jensen 1996, Coppin et al. 2004, Hu et al. 2004, Lu et al. 2004).

(d)

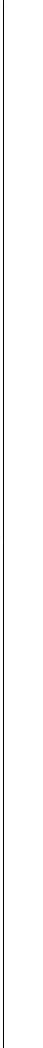




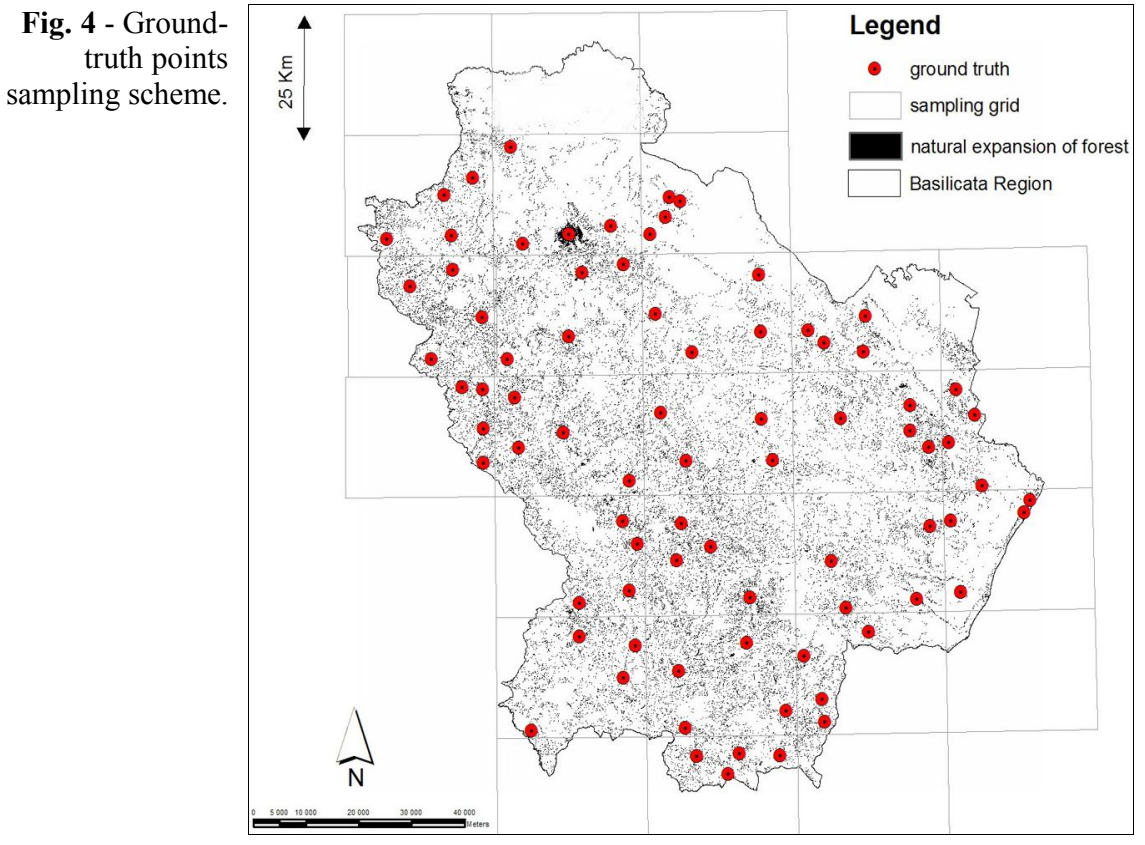

Generally, the threshold value is identified by $n \cdot \sigma$ of the NDVI difference image average, where the $n$ value is identified by the trial and test method, and $\sigma$ is the standard

Tab. 1 - Parameters of the distribution of the NDVI difference image values. $(* *): p<$ 0.01 .

\begin{tabular}{ll}
\hline Parameter & Value \\
\hline Mean & 0.01 \\
Median & 0.01 \\
Mode & 0.011 \\
Standard Deviation & 0.101 \\
Skewness & -0.127 \\
St. Error of Skewness & 0.025 \\
Kurtosis & 1.927 \\
St. Error of Kurtosis & 0.049 \\
KS Test & $0.0756^{* *}$ \\
\hline
\end{tabular}

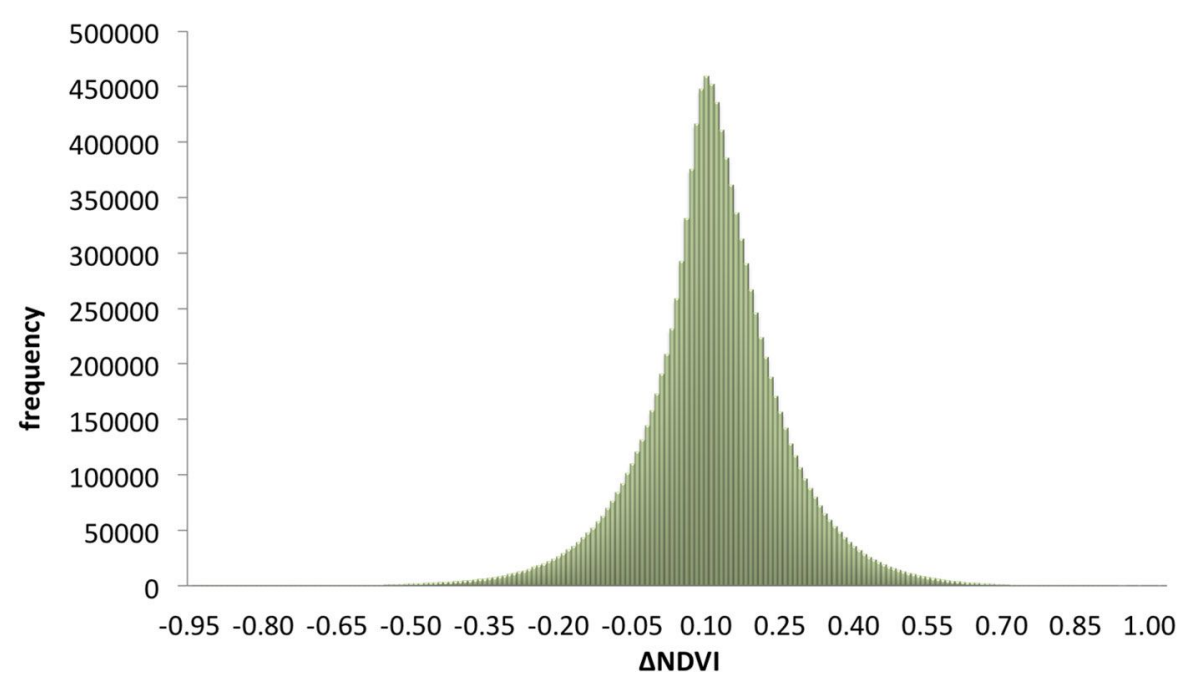

Fig. 5 - Distribution of $\Delta$ NDVI pixel values.
Landsat TM RGB band compositions were selected (Fig. 3) since their efficient representation of the vegetation cover (Lillesand \& Kiefer 1999, Gibson \& Power 2000, Horning et al. 2010). Landsat TM4-3-2 is commonly used for the identification of broad leaf, conifers, grasslands, sparsely vegetated areas and/or healthier vegetation (Jensen 2000, Dehnavi et al. 2010). Landsat TM4-5-3 is used for the discrimination of vegetation types and conditions and land/water interface (Jensen 1996). The composition Landsat TM4-5-1 is particularly efficient in the detection of healthy vegetated areas, but also for recently clear-cut regions and new vegetative growth generally attributed to sparse grasslands (Short 1982, Lillesand \& Kiefer 1999). Landsat TM7-4-2 was analyzed for the detection of low-density vegetation that can represent areas with probable natural expansion due to forest processes (Richards \& Xiuping 2006). The composition Landsat TM5-4-1 representing healthy vegetation and is generally used for the detection of agricultural areas (Wallace et al. 2006). In addition to the RGB band combinations, the Landsat TM band ratios were analyzed using the Landsat TM4/TM3 and TM3/TM2. The TM4/TM3 ratio distinguishes vegetation, water, and croplands, while the TM3/TM2 ratio separates forests and croplands, which is useful in discriminating broad classes of vegetation (Sabins 1997). Finally, the $n \cdot \sigma$ threshold value was statistically determined by Cohen's Kappa interrater agreement coefficient (Cohen 1960, Story \& Congalton 1986, Congalton 1991, Jenness \& Wynne 2005), which identified $n$ $=1.5$.

\section{Ground-truth validation}

Natural expansion of forest areas within positive vegetation change was detected by clipping the NDVI $>+1.5 \cdot \sigma$ image using a mask image of the Forest Map for Basilicata (Costantini et al. 2006), which represented the actual forest cover extension, and also included the area subject to natural forest expansion. The five year difference between the Forest Map (2006) publication and the change detection analysis (2010) resulted in the application of a $100 \mathrm{~m}$ buffer to identify any pixel with $\Delta \mathrm{NDVI}>+1.5 \cdot \sigma$ that can be considered as a possible natural forest expansion during this period. The buffer value was chosen on the basis of the spatial characteristics of forest cover that in many cases is highly fragmented with high perimetral values. Finally, the pixels characterized by $\Delta$ NDVI $>+1.5 \cdot \sigma$ within the conifer afforestation and plantation forest types were excluded.

Eighty points were selected by a random stratified sampling approach to validate the proposed methodology. The study area was divided into a $25 \times 25 \mathrm{~km}$ grid (Fig. 4), with 
Tab. 2 - Threshold value accuracy assessments. The producer's accuracy refers to the probability of land-cover classification accuracy. (a): Error of natural expansion of forest classified as others; $(\mathrm{K})$ : Cohen's Kappa inter-rater agreement coefficient.

\begin{tabular}{ccccc}
\hline Threshold & $\begin{array}{c}\text { Producer's } \\
\text { Accuracy }\end{array}$ & $\begin{array}{c}\text { Overall } \\
\text { Accuracy }\end{array}$ & $\begin{array}{c}\text { Error } \\
\mathbf{( \% )}\end{array}$ & $\begin{array}{c}\text { Overall } \\
\text { K }\end{array}$ \\
\hline $1 \cdot \sigma$ & 0.88 & 0.83 & 13.9 & 0.23 \\
$1.5 \cdot \sigma$ & 0.95 & 0.94 & 5.1 & 0.61 \\
$2 \cdot \sigma$ & 0.8 & 0.77 & 25.2 & 0.1 \\
\hline
\end{tabular}

Fig. 6 - Comparison of Landsat TM RGB band compositions (TM4-3-2) of two test areas for the year $1984(a, b)$ and $2010(\mathrm{c}, \mathrm{d})$.
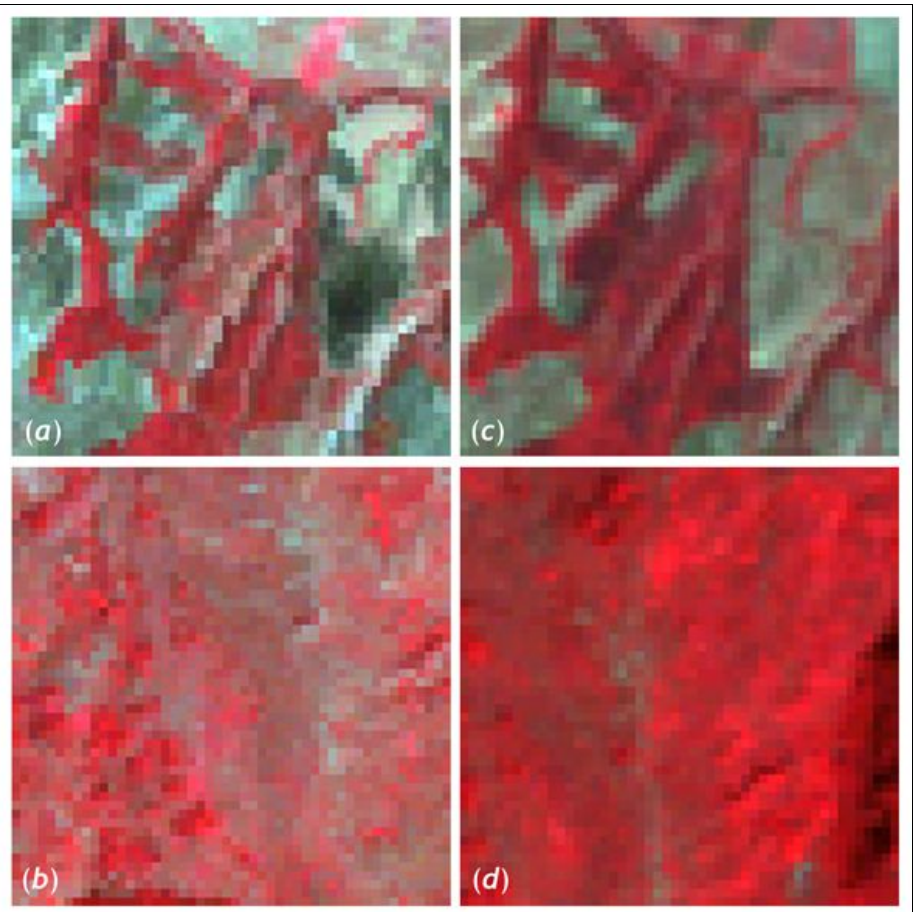

Fig. 7 - Comparison of digital aerial orthophotos for two test areas based on images from Volo Italia $1994(\mathrm{a}, \mathrm{b})$ and TerraItaly 2008 (c, d).
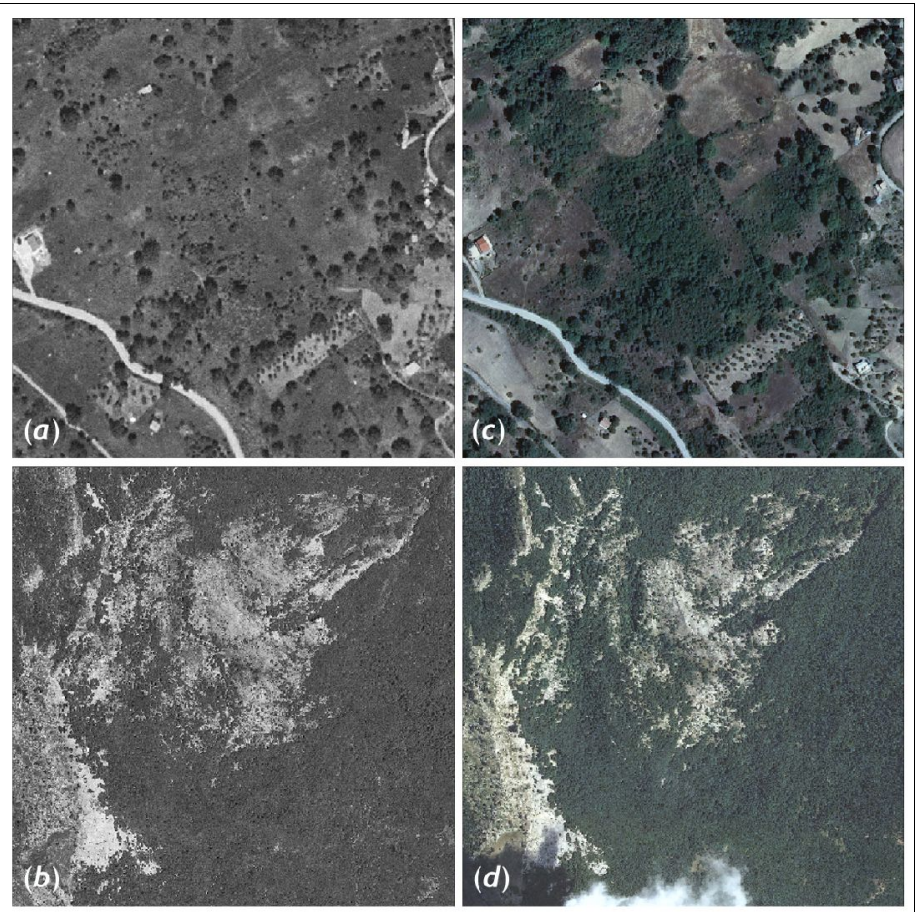

four validation points for each cell randomly chosen among the pixels with $\triangle$ NDVI > $+1.5 \cdot \sigma$. The random stratified sampling approach ensured good cover over the regional forest areas, and at the same time randomness of points within each grid cell. Each of the 80 points was ground-checked using GPS to validate the presence of natural forest expansion processes.

\section{Results and Discussion}

Natural expansion of forests in the Basilicata region study area was examined by the NDVI differencing approach. According to the purpose of the study, only positive variations of NDVI were considered, with the exclusion of negative changes that were considered negligible. In particular negative changes of NDVI, in terms of loss of forest cover, are mainly represented by forest fires accounting yearly for the $0.1 \%$ of total forest cover. Moreover, no deforestation processes are reported according to the Regional law which prevents any land use change on forest ecosystems.

The main parameters of the distribution of $\Delta$ NDVI image values are reported in Tab. 1 . Mean, mode, and median values were close to zero, as well as skewness, indicating a good distribution symmetry (Fig. 5). The goodness-of-fit of the $\triangle$ NDVI image values to a normal distribution was also verified by Kolmogorov-Smirov non-parametric test. Although the KS test indicates a departures from normal distribution $(\mathrm{p}>0.01)$, it is still within the range normally accepted in the literature in order to be considered a normal or near-normal distribution.

Threshold detection was carried out through visual analysis of Landsat TM RGB band compositions and ratios and their comparison across the two year considered (Fig. 6). The area of actual natural forest expansion was also better identified by comparing the digital aerial orthophotos (1994-2008 Fig. 7). The best accuracy in the detection of natural forest expansion was obtained using a threshold of $1.5 \cdot \sigma$ with $\Delta \mathrm{NDVI}=\mu+1.5 \cdot \sigma$, as reported in Tab. 2.

This result is consistent with that obtained by similar studies using the same methodology. In particular, the above test and trial approach was applied to detect vegetation changes due to human-induced rapid land use alterations in tropical forest ecosystems as reported by Miller et al. (1978) in Thailand, Phuaa et al. (2008) in Malaysia, and Sinch (1986) in India based on Landsat imagery. In addition, Hayes \& Sader (2001) in Guatemala, and Petit et al. (2001) and Braimoh \& Vlek (2004) in Africa applied the same technique to detect forest clearing and vegetation regrowth.

The trial and test approach was also used in forest management for clear-cuts and regrowth detection in temperate forest ecosys- 
tems (Banner \& Lynham 1981, Hayes \& Sader 2001), and for the identification of selective logging (Win et al. 2012). Sepehry \& Liu (2006) used symmetric threshold identification by testing threshold values ranging between $1 \cdot \sigma$ and $2 \cdot \sigma$ to monitor land cover change induced by flood, while Sarp (2012) used $1 \cdot \sigma$ threshold to detect vegetation change and main environmental effects of surface mining activities. Jomaa \& Bou Keir (2003) reported anthropogenic land use change detection with the trial and test approach, and determined $2 \cdot \sigma$ was the optimal threshold value for two sites in Lebanon. Yacouba et al. (2009) applied $1 \cdot \sigma$ in Yunnan province (China), while Podeh et al. (2009) and Coban et al. (2010) ascertained $2 \cdot \sigma$ was the optimal value for land use change detection over complex vegetation cover. Finally, Pu et al. (2008) tested different threshold values ranging between $1 \cdot \sigma$ and $2 \cdot \sigma$ to determine real changes in sparse vegetation cover composed of shrubby trees colonizing riparian areas in Nevada. In some cases, the threshold identification was obtained from extreme percentile values of the NDVI difference image for evaluation of vegetation changes in drainage basin forests (Ferrarini et al. 2000, Mandrone et al. 2006), or forests in hydrogeologically unstable areas (Del Barba et al. 2006). Other more complex threshold identification methods have been recently proposed (Metternicht 1999, Bruzzone \& Fernandez Prieto 2000a, 2000b, Hodgson et al. 2004, Im et al. 2007, Boone et al. 2007, Almutairi \& Warner 2010). Nevertheless, due to its simplicity, the image thresholding method based on standard deviation remains the most commonly used method for the detection in vegetation changes.

Based on the results obtained in this analysis, the $\Delta$ NDVI $>+1.5 \cdot \sigma$ image was extracted and clipped using the Basilicata Region Forest Map mask with a $100 \mathrm{~m}$ buffer as specified in the Material and Methods. The resulting image (Fig. 8) shows the areas of likely natural forest expansion used for the identification of the ground validation points based on the random stratified sampling.

Among the 80 ground validation points selected, only six were not accessible due to topographic constraints. As for the remaining 74 points (Tab. 3), the vegetation changes detected were the result of natural forest expansion processes in $91.9 \%$ of the cases (68 points), while in $8.1 \%$ (6 points) the proposed method failed to detect natural forest expansion. In two cases, the failure was due to the coppice revegetation after harvesting; in a single case, the vegetation change was determined by conifer afforestation in a degraded broadleaf forest. Other sources of error were related to revegetation after a fire event in Mediterranean Macchia (one point), and incorrect attribution of land

Tab. 3 - Ground-truth validation results.

\begin{tabular}{lccl}
\hline Cover type & $\begin{array}{c}\text { Samples } \\
\text { (n) }\end{array}$ & $\begin{array}{c}\text { Accuracy } \\
(\%)\end{array}$ & Characteristics \\
\hline $\begin{array}{l}\text { Natural } \\
\text { afforestation }\end{array}$ & 68 & 91.8 & - \\
$\begin{array}{l}\text { Others } \\
\text { Total }\end{array}$ & 6 & 8.1 & $\begin{array}{l}\text { Forest harvesting (2), conifer afforestation in } \\
\text { broadleaf forest (1), revegetation after forest fire (1), } \\
\text { other land covers (2) } \\
-\end{array}$ \\
\hline
\end{tabular}

Tab. 4 - Comparisons between natural afforestation from NDVI differencing methodology and inventory forest cover increments.

\begin{tabular}{lcc}
\hline Method & $\begin{array}{c}\text { Forest cover } \\
\text { increment } \\
\text { ha (\%) }\end{array}$ & $\begin{array}{c}\text { Forest cover } \\
\text { annual increment } \\
\left(\mathbf{h a ~ y r}^{-1}\right)\end{array}$ \\
\hline NDVI differencing (1984 - 2010) & 70154 & 2698 \\
National Forest Inventories (1984 - 2005) & $\begin{array}{c}(19.7) \\
(17.4)\end{array}$ & 2958 \\
Difference between methods & 8028 & - \\
& $(2.3)$ & \\
\hline
\end{tabular}

cover classes (an olive grove in one case). One last source of error was related to a strong NDVI increase within a forest stand, likely the result of a significant increase in forest density, or to enhanced environmental conditions for growth in recent years. In this specific case, the source of error could be related to quality differences between the two images analyzed. Overall, the accuracy of the ground-based validation reported in Tab. 3 is consistent with that reported in other studies using the NDVI differencing tech- nique (Hayes \& Sader 2001, Podeh et al. 2009, Anderson 2008, Pu et al. 2008, Wang \& Xu 2010).

Our results indicated that in the period 1984-2010 approximately 70154 ha were affected by natural forest expansion processes in the study area, with an annual forest cover increase of 2698 ha (Tab. 4). Given the actual forest cover extension (355 367 ha) as provided by the Basilicata Region Forest Map (Costantini et al. 2006), the increase of forest cover between 1984 and

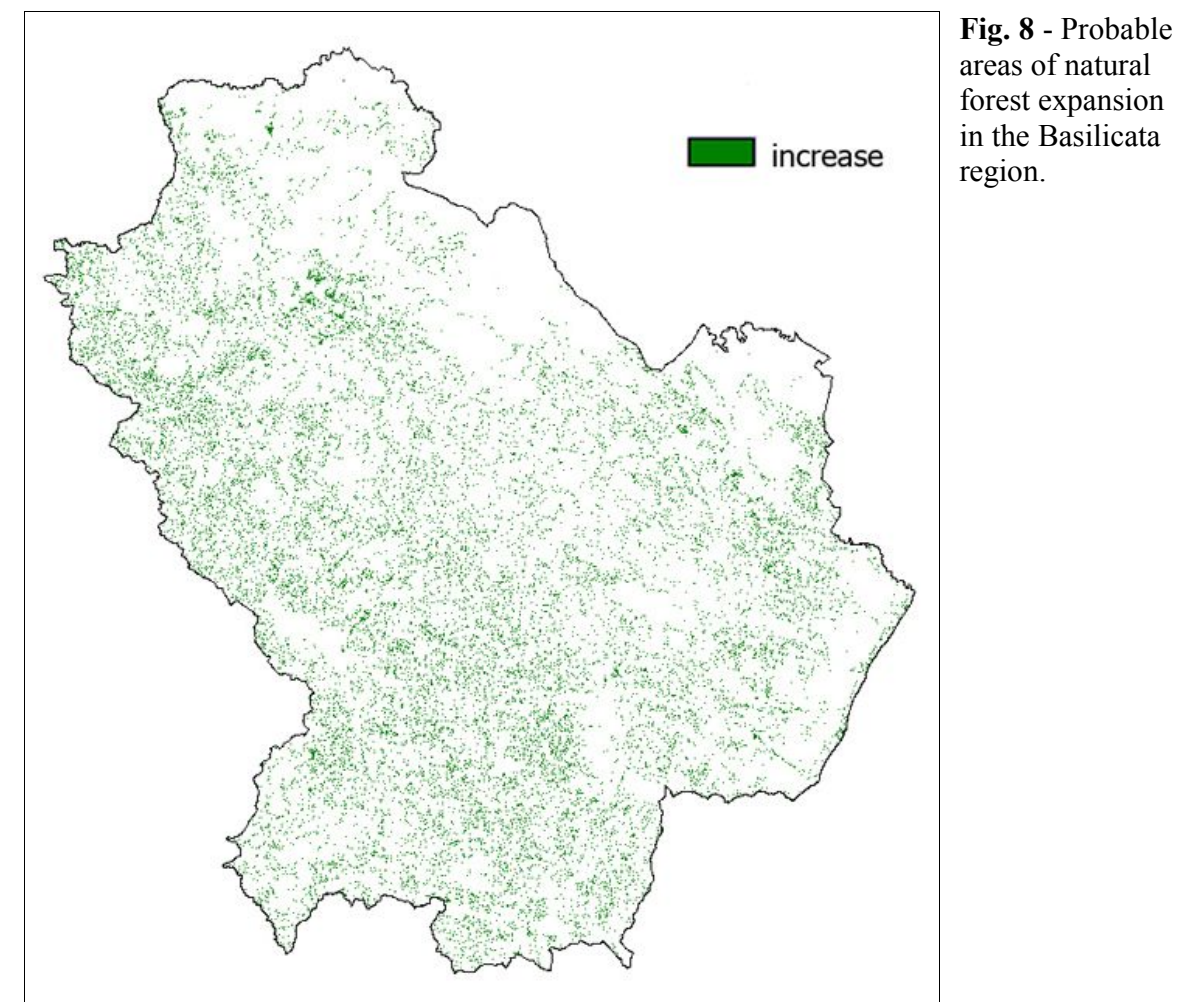


Fig. 9 - Natural forest expansion on abandoned cattleraising area for Beech forest in the Pollino National Park area.

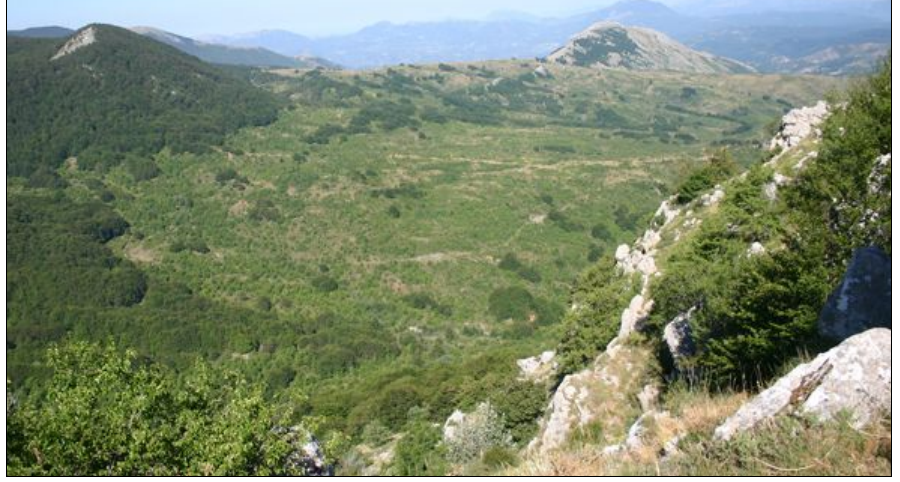

Fig. 10 - Natural forest expansion of the Mediterranean macchia vegetation type in a droughtprone Calanchi area.

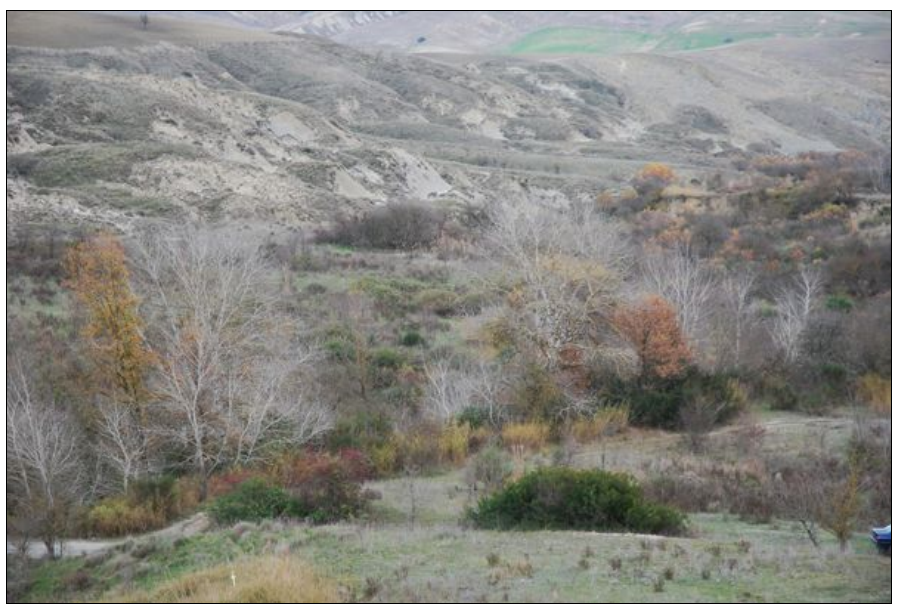

2010 was approximately $19.7 \%$. Similar figures may be obtained by comparing forest cover extensions from two consecutive $\mathrm{Na}$ tion Forest Inventories carried out in $\mathrm{Ba}$ silicata over the same period (294 300 ha IFN 1988; 356426 ha - INFC 2005). The difference between the two above inventories (62 126 ha of increase in forest cover) was very close to the value reported in the present study (70 154 ha). The difference between the two latter estimates (8028 ha) may be explained by a further forest expansion occurred over the five years intervening between the last National inventory (2005) and the 2010 Landsat TM image used as reference in this analysis.

Values of natural forest expansion obtained in this study are slightly higher than those reported by the IUTI (Inventario dell'Uso delle Terre) land use inventory for the $\mathrm{Ba}$ silicata region in the period 1990-2008 (Corona et al. 2012). However, this discrepancy may be explained. First, the overall forest cover extension reported by the IUTI inventory for the study area was lower (331 667 ha, approximately $0.7 \%$ ) than that provided by the Basilicata Region Forest Map (-6.7\%), since the latter was based on continuous field recognition rather than on sampling points as for the former. Further- more, the different time span analyzed (1990-2008 vs. 1984-2010) may accidentally include different trends in main drivers of natural forest expansion, such as forest growth patterns or land abandonment in marginal areas.

Our results also emphasizes some important characteristics of the natural forest expansion in the study area. Indeed, it occurs in areas characterized by severe climate, morphological, and pedological conditions. In $11.4 \%$ of the cases analyzed, forest expansion has been detected in areas affected by extreme temperatures (annual mean temperature between $16-18{ }^{\circ} \mathrm{C}$ ), and in $28.3 \%$ of cases in areas with average annual rainfall of $500-700 \mathrm{~mm}$. According to the Bagnouls \& Gaussen (1953) index (BGI), 20.8\% of natural forest expansion occurred in dry areas with BGI 50-130. These results were also cross-classified with the ESA (Environmental Sensitive Areas) map (Basso et al. 1999, Kosmas et al. 2000, Ferrara et al. 2005, 2010), which presented trends in natural forest expansion. According to the ESA classification, natural forest expansion occurred within the vulnerability class $\mathrm{F}$ (Fragile 29.7\%) and class C (Critical - 3.2\%).

Our results also support some interesting consideration on the vegetation types subject to natural forest expansion. Although $48.9 \%$ of the increment was due to deciduous oak forests, a consistent part of it occurred in the meso/thermophiles component of this vegetation type. Furthermore, natural forest expansion occurred for the Mediterranean macchia $(11.4 \%)$ and garrigue $(2 \%)$. Beech forests (Fig. 9) and Mediterranean macchia (Fig. 10) in drought-prone Calanchi areas also showed a natural forest expansion in cattle-raising abandoned areas generally covered by shrubbery followed by tree restoration. The above results highlight the natural forest expansion occurring on degraded and drought-prone soils of the Mediterranean areas, a regions considered highly vulnerable to desertification. Due to their intrinsic ecologic interest, these areas require further study to examine their vegetation potential and dynamics.

\section{Conclusions}

The present study demonstrated how satellite-based detection of vegetation change can provide reliable results in the assessment of natural expansion of forests and of forest cover dynamics. The validation of the method used by visual analysis of aerial orthophotos and comparison with ground-level sampling control points allowed a reliable identification of vegetation changes due to natural forest expansion. Finally, the relative simplicity of the methodology and the availability of time series Landsat TM images at low cost favors the application of the approach described to large scale forest inventories. Our results also emphasized the current natural forest expansion occurring in drought-prone Mediterranean areas, always considered as highly vulnerable to desertification, and therefore difficult to be managed for purposes of environmental protection. The information on forest cover dynamics provided in this study can be considered a useful starting point to further analyze spatial and temporal patterns of vegetation changes in degraded areas.

\section{Acknowledgements}

This research was supported by Italian MIUR (PRIN-20085FL4E4_002) "Quantifying carbon stock changes in revegetated forests stands in the Mediterranean environments" (P.I. Agostino Ferrara).

\section{References}

Almutairi A, Warner AT (2010). Change detection accuracy and image properties: a study using simulated data. Remote Sensing 2: 1508-1529. doi: $10.3390 /$ rs2061508

Anderson L (2008). Using classification and NDVI differencing methods for monitoring sparse vegetation coverage: a case study of saltcedar in Nevada, USA. International Journal of Remote Sensing 29 (14): 3987-4011. - doi: $10.1080 / 01431160701767435$ 
Bagnouls F, Gaussen H (1953). Saison séche et indice xérothermique. Document pour les Cartes des Productions végétales, Toulouse, France, Tome 3, vol. 1, pp. 47.

Balanda KP, MacGillivray HL (1988). Kurtosis: a critical review. The American Statistician 42 (2): 111-119.

Banner AV, Lynham T (1981). Multitemporal analysis of LANDSAT data for forest cutover mapping: a trial of two procedures. In: Proceedings of the " $7^{\text {th }}$ Canadian Symposium on Remote Sensing". Canadian Remote Sensing Society, Winnipeg, MB, Canada, pp. 233-240.

Basso F, Bellotti A, Faretta S, Ferrara A, Mancino G, Pisante M, Quaranta G, Taberner M (1999). Application of the proposed methodology for defining ESAs: the Agri basin. In: "The Medalus project Mediterranean desertification and land use. Manual on key indicators of desertification and mapping environmentally sensitive areas to desertification" (Kosmas C, Kirkby, Geeson N eds). Report no. 18882, European Union, Brussels, Belgium, pp. 74-79. [ISBN 92-828-6349-2] Biondi E, Casavecchia S, Pesaresi S (2006). Spontaneous renaturalization processes of the vegetation in the abandoned fields (Central Italy). Annali di Botanica 6: 65-93.

Boone RB, Lackett JM, Galvin KA, Dennis S, Ojima DS, Compton J, Tucker III CJ (2007). Links and broken chains: evidence of human-caused changes in land cover in remotely sensed images. Environmental Science and Policy 10: 135-149. - doi: 10.1016/j.envsci 2006.09.006

Braimoh AK, Vlek PL (2004). Land-cover change analyses in the Volta basin of Ghana. Earth Interactions 8 (21): 1-17. - doi: 10.1175/10873562(2004)8<1:LCAITV>2.0.CO;2

Bruzzone L, Fernandez Prieto D (2000a). Automatic analysis of the difference image for unsupervised change detection. IEEE Transactions on Geoscience and Remote Sensing 38: 1171-1182. - doi: 10.1109/36.843009

Bruzzone L, Fernandez Prieto D (2000b). A minimum-cost thresholding technique for unsupervised change detection. International Journal of Remote Sensing 21: 3539-3544. - doi: 10.1080/ 014311600750037552

Callahan K (2001). Validation of a radiometric normalization procedure for satellite derived imagery within a change detection framework. M.Sc., Utah State University, Salt Lake City, USA. [online] URL: http://www.nr.usu.edu/ doug/serdp/Pubs/Grads/KCthesislpro.pdf

Cantore V, Iovino F, Pontecorvo G (1987). Aspetti climatici e zone fito-climatiche della $\mathrm{Ba}$ silicata. C.N.R. IEIF, Cosenza, Grafiche Badiali, Arezzo, Italy, pp. 50. [in Italian]

Chavez PS (1996). Image-based atmospheric corrections'revisited and revised. Photogrammetric Engineering and Remote Sensing 62 (9): 10251036. [online] URL: http://www.unc.edu/ courses/2008spring/geog/577/001/www/Chavez9 6-PERS.pdf

Coban HO, Koc A, Eker M (2010). Investigation on changes in complex vegetation coverage using multi-temporal landsat data of Western Black sea region - a case study. Journal of Environmental Biology 31: 169-178. [online] URL: http://imsear.hellis.org/handle/123456789/14634 5

Cohen J (1960). A coefficient of agreement for nominal scales. Educational and Psychological Measurement 1: 37-46. - doi: 10.1177/00131644 6002000104

Cohen WB, Fiorella M (1998). Comparison of methods for detecting conifer forest change with Thematic Mapper imagery. In: "Remote Sensing Change Detection: Environmental Monitoring Methods and Applications" (Lunetta RS, Elvidge CD eds). Ann Arbor Press, Chelsea, MI, USA, pp. 318.

Congalton RG (1991). A review of assessing the accuracy of classifications of remotely sensed data. Remote Sensing of Environment 37: 35-46. - doi: 10.1016/0034-4257(91)90048-B

Coppin PR, Bauer ME (1996). Digital change detection in forest ecosystems with remotely sensed imagery. Remote Sensing Reviews 13: 207-234. - doi: 10.1080/02757259609532305

Coppin P, Jonckheere I, Nackaerts K, Muys B, Lambin E (2004). Digital change detection methods in ecosystem monitoring; a review. International Journal of Remote Sensing 25: 15651596. - doi: 10.1080/0143116031000101675

Corona P, Barbati A, Tomao A, Bertani R, Valentini R, Marchetti M, Fattorini L, Perugini L (2012). Land use inventory as framework for environmental accounting: an application in Italy. iForest 5: 204-209. - doi: 10.3832/ifor0625-005 Costantini G, Bellotti A, Mancino G, Borghetti M, Ferrara A (2006). Carta forestale della Basilicata - Atlante. INEA - Regione Basilicata, Potenza, pp. 99. [ISBN 88-8145-062-3] [in Italian]

De Beurs KM, Henebry GM (2005). A statistical framework for the analysis of long image time series. International Journal of Remote Sensing 26 (8): 1551-1573. - doi: 10.1080/01431160512 331326657

Del Barba O, Pecci A, Rossi O, Rossi P, Zaccarelli N, Zurlini G (2006). Modelli statistici nell'analisi dell'evoluzione dell'NDVI (Normalized Difference Vegetation Index) in Val Pola (Valtellina) prima e dopo la frana del Monte Coppetto (28 luglio 1987). In: Prooceedings of the " $16^{\text {th }}$ Meeting of the Italian Society of Ecology". Viterbo/Civitavecchia (Italy) 19-22 Sep 2006, pp. 1-6. [in Italian] [online] URL: http://www.ecologia.it/congressi/XVI/articles/ros si-229.pdf

Dehnavi AG, Sarikhani R, Nagaraju D (2010). Image processing and analysis of mapping alteration zones in environmental research, east of Kurdistan, Iran. World Applied Sciences Journal 11 (3): 278-283. [online] URL: http://www. idosi.org/wasj/wasj11(3)/5.pdf

Desclée B, Bogaert P, Defourny P (2006). Forest change detection by statistical object-based method. Remote Sensing of Environment 102: 1-11. - doi: 10.1016/j.rse.2006.01.013

Elvidge CD, Yuan D, Weerackoon RD, Lunetta RS (1995). Relative radiometric normalization of
Landsat Multispectral Scanner (MSS) data using and automatic scattergram-controlled regression. Photogrammetric Engineering and Remote Sensing 61 (10): 1255-1260.

Ferrara A, Bellotti A, Faretta S, Mancino G, Baffari P, D'ottavio A, Trivigno V (2005). Map of desertification-prone areas in the Basilicata region, Italy. Forest@ 2 (1): 66-73. [in Italian with english abstract] - doi: 10.3832/efor0255-002 0066

Ferrara A, Mancino G, Urbano V, Coletta V, Baffari $P$ (2010). Review on the use and the application of the ESA (Environmental Sensitive Areas) methodology and updating of the map of environmental sensitivity areas to desertification for the Basilicata Region, Italy. Forest@ 7 (1): 133 147. [in Italian with English abstract] - doi: 10.3832/efor0627-007

Ferrarini A, Zaccarelli N, Rossi P, Cristiano D, Orlandini L (2000). Change detection degli habitat corine nel bacino del torrente Baganza (Parma) attraverso l'indice NDVI. Rivista Italiana di Telerilevamento 19: 29-35. [in Italian]

Fiorenzo F, Mancino G, Borghetti M, Ferrara A (2008). Spatial interpolation methods for monthly rainfalls and temperatures in Basilicata. Forest@ 5 (1): 337-350. [in Italian with English abstract] - doi: 10.3832/efor0550-0050337

Friedl MA, McIver DK, Hodges JCF, Zhang XY, Muchoney D, Strahler AHW, Gopal S, Schneider A, Cooper A (2002). Global land cover mapping from MODIS: Algorithms and early results. Remote Sensing of Environment 83: 287-302. - doi: 10.1016/S0034-4257(02)00078-0

Friedl MA, Sulla-Menashe D, Tan B, Schneider A, Ramankutty N, Sibley A, Huang X (2010). MODIS Collection 5 global land cover: algorithm refinements and characterization of new datasets. Remote Sensing of Environmen 114: 168-182. - doi: 10.1016/j.rse.2009.08.016

Gibson PJ, Power CH (2000). Introductory remote sensing: digital image processing and applications. Taylor and Francis Inc., New York, USA, pp. 58-63.

Giri CP (2012). Remote sensing of land use and land cover: principles and applications remote sensing applications series. USGS/Earth EROS Center, CRC Press, Boca Raton, FL, USA, pp. 477.

Groeneveld RA, Meeden G (1984). Measuring Skewness and Kurtosis. The Statistician 33 (4): 391-399. - doi: 10.2307/2987742

Hayes DJ, Sader SA (2001). Comparison of change-detection techniques for monitoring tropical forest clearing and vegetation regrowth in a time series. Photogrammetric Engineering and Remote Sensing 67: 1067-1075. [online] URL: http://www.asprs.org/a/publications/pers/2001 journal/september/2001_sep_1067-1075.pdf Hodgson ME, Li X, Cheng Y (2004). A parameterization model for transportation feature extraction. Photogrammetric Engineering and Remote Sensing 70 (12): 1399-1404. [online] URL: http://www.asprs.org/a/publications/pers/2004journal/december/2004_dec_1399-1404.pdf Horning N, Robinson AJ, Sterling EJ, Turner W, 
Spector S (2010). Remote sensing for ecology and conservation. A handbook of techniques. Oxford University Press, Oxford, UK, pp. 448. [ISBN 13:9780199219957]

Hu Y, De Jong SM, Sluiter R (2004). A modelingbased threshold approach to derive change/no change information over vegetation area. In: Proceedings of the " $12^{\text {th }}$ International Conference on Geoinformatics - Geospatial Information Research: Bridging the Pacific and Atlantic". University of Gävle (Sweden) 7-9 June 2004, pp. 647 654. [online] URL: http://fromto.hig.se/ bjg/geo informatics/files/p647.pdf

IFN (1988). IFN Inventario Forestale Nazionale 1985: sintesi metodologica e risultati. Ministero dell'Agricoltura e delle Foreste, Direzione Generale delle Risorse Forestali, Montane ed Idriche, Corpo forestale dello Stato, Istituto sperimentale per l'Assestamento e per l'Alpicoltura, Trento, Italy, pp. 462. [in Italian]

Im J, Rhee J, Jensen JR, Hodgson ME (2007). An automated binary change detection model using a calibration approach. Remote Sensing of Environment 106: 89-105. - doi: 10.1016/j.rse.2006 .07 .019

INFC (2005). Inventario Nazionale delle Foreste e dei Serbatoi Forestali di Carbonio. Ministero delle Politiche Agricole Alimentari e Forestali, Ispettorato Generale, Corpo Forestale dello Stato, CRA - Istituto Sperimentale per l'Assestamento Forestale e per l'Alpicoltura, Trento, Italy. [in Italian]

IPCC (2007). Climate change 2007: the physical science basis. Contribution of Working Group to the $4^{\text {th }}$ Assessment Report of the IPCC (Solomon S, Qin D, Manning M, Chen Z, Marquis M, Averyt KB, Tignor M, Miller HL eds). Cambridge University Press, Cambridge, UK and New York, NY, USA.

ISTAT (2001). $14^{\circ}$ Censimento della popolazione e delle abitazioni. Istituto Nazionale di Statistica, web site. [in Italian] [online] URL: http://da winci.istat.it/daWinci

Jenness J, Wynne JJ (2005). Cohen's Kappa and classification table metrics 2.0: an ArcView 3x extension for accuracy assessment of spatially explicit models. Open-File Report OF 20051363, US Geological Survey, Southwest Biological Science Center, Flagstaff, AZ, USA.

Jensen JR (1996). Introductory digital image processing: a remote sensing perspective $\left(2^{\text {nd }}\right.$ edn $)$. Prentice Hall, New Jersey,USA.

Jensen JJ (2000). Remote sensing of the environment, an earth resource perspective. Prentice Hall, Upper Saddle River, NJ, USA, pp. 544. [ISBN 0-13-489733-1]

Jomaa I, Bou Keir R (2003). Multitemporal unsupervised classification and NDVI to monitor land cover change in Lebanon. Options Méditerranéennes Série B 46: 43-49.

Justel A, Peña D, Zamar R (1997). A multivariate Kolmogorov-Smirnov test of goodness-of-fit. Statistics and Probability Letters 35 (3): 251259. - doi: 10.1016/S0167-7152(97)00020-5

Kendall MG, Stuart A (1969) The advanced theory of statistics. Vol. 1 ( $3^{\text {rd }}$ edn). Charle Griffin and Company Ltd., London, UK, pp. 439.

Kosmas C, Ferrara A, Bellotti A, Detsis V, Faretta S, Gerontidis S, Mancino G, Marathainou M, Pisante M (2000). A comparative analysis of the physical environment of two Mediterranean areas threatened by desertification. In: "Mediterraneo". Istituto Mediterranico, Universitade Nova De Lisboa, Lisboa, Portugal.

Lilliefors HW (1967). On the KolmogorovSmirnov test for normality with mean and variance unknown. Journal of the American Statistical Association 62 (318): 399-402. - doi: 10.1080/01621459.1967.10482916

Lillesand TM, Kiefer RW (1999). Remote sensing and image interpretation ( $4^{\text {th }}$ edn). John Wiley and Sons Inc., New York, NY, USA, pp. 724. [ISBN 0-471-25515-7]

Lu D, Weng Q (2007). A survey of image classification methods and techniques for improving classification performance. International Journal of Remote Sensing 28: 823-870. - doi: 10.1080/ 01431160600746456

Lu D, Mausel P, Batistella M, Moran E (2004). Comparison of land-cover classification methods in the Brazilian Amazonia basin. Photogrammetric Engineering and Remote Sensing 70: 723731.

Lu D, Mausel P, Brondizio E, Moran E (2002). Assessment of atmosheric correction methods for Landsat TM data applicable to Amazon basin LBA research. International Journal of Remote Sensing 13: 2651-2671. - doi: 10.1080/014311 60110109642

Lunetta RS, Ediriwickrema J, Johnson DM, Lyon JG, McKerrow A (2002). Impacts of vegetation dynamics on the identification of land-cover change in a biologically complex community in North Carolina, USA. Remote Sensing of Environment 82: 258-270. - doi: 10.1016/S0034-42 57(02)00042-1

Lunetta RS, Knight JF, Ediriwickrema J, Lyon JG, Worthy LD (2006). Land-cover change detection using multi-temporal MODIS NDVI data. Remote Sensing of Environment 105: 142-154. doi: 10.1016/j.rse.2006.06.018

Lyon JG, Yuan D, Lunetta RS, Elvidge CD (1998). A change detection experiment using vegetation indices. Photogrammetric Engineering and Remote Sensing 64 (2): 143-150. [online] URL: http://www.asprs.org/a/publications/pers/ 98journal/february/1998 feb 143-150.pdf

Mancino G, Nolè A, Urbano V, Amato M, Ferrara A (2009). Assessing water quality by remote sensing in small lakes: the case study of Monticchio lakes in Southern Italy. iForest 2: 154-161. - doi: 10.3832/ifor0507-002

Mandrone S, Rossi D, Rossi L (2006). Metodo di stima della fragilità intrinseca di habitats boschivi nei bacini di drenaggio di laghi Vulcanici. In: Proceedings of the " $16^{\text {th }}$ Meeting of the Italian Society of Ecology". Viterbo/Civitavecchia (Italy) 19-22 September 2006, pp. 1-7. [online] URL: http://www.ecologia.it/congressi/XVI/articles/mandrone-220.pdf

Martinez B, Gilabert MA (2009). Vegetation dynamics from NDVI time series analysis using the wavelet transform. Remote Sensing of Environment 113:1823-1842. - doi: 10.1016/j.rse.2009. 04.016

Mas JF (1999). Monitoring land-cover changes: a comparison of change detection techniques. International Journal of Remote Sensing 20:139152. - doi: 10.1080/014311699213659

Mateos CJB, Pinilla CP, Gonzalez-Crespo R, Castillo-Sanz AC (2010). Relative radiometric normalization of multitemporal images. International Journal of Artificial Intelligence and Interactive Multimedia 1(3): 54-59 [online] URL: http://dialnet.unirioja.es/servlet/articulo? codigo= 4036657

Metternicht G (1999). Change detection assessment using fuzzy sets and remotely sensed data: an application of topographic map revision. ISPRS Journal of Photogrammetry and Remote Sensing 54:221-233. - doi: 10.1016/S0924-2716 (99)00023-4

Metz B, Davidson OR, Bosch PR, Dave R, Meyer LA (2007). Contribution of Working Group III to the $4^{\text {th }}$ Assessment Report of the IPCC. Cambridge University Press, Cambridge, UK and New York, NY, USA.

Miller LD, Nualchawee K, Tom C (1978). Analysis of the dynamics of shifting cultivation in the tropical forests of northern Thailand using landscape modelling and classification of Landsat imagery. NASA Tech. Mem. 79545, Goddard Space Flight Center, Greenbelt, MD, USA, pp. 19.

Milne AK (1988). Change detection analysis using Landsat imagery: a review of methodology. In: Proceedings of the "IGARSS 1988 Symposium". Edinburgh (Scotland - UK), European Space Agency, Neuilly, France, 13-16 September 1988, pp. 541-544.

Muchoney DM, Haack BN (1994). Change detection for monitoring forest defoliation. Photogrammetric Engineering and Remote Sensing 60: 1243-1251. [online] URL: http://cat.inist.fr/? aModele $=$ afficheN\&cpsidt $=3326730$

Nabuurs GJ, Masera O, Andrasko K, Benitez-Ponce P, Boer R, Dutschke M, Elsiddig E, Ford-Robertson J, Frumhoff P, Karjalainen T, Krankina O, Kurz WA, Matsumoto M, Oyhantcabal W, Ravindranath NH, Sanz Sanchez MJ, Zhang X (2007). Forestry. In: "Climate Change 2007: Mitigation" (Metz B, Davidson OR, Bosch PR, Dave R, Meyer LA eds). Contribution of Working Group III to the $4^{\text {th }}$ Assessment Report of the IPCC. Cambridge University Press, Cambridge, UK and New York, NY, USA.

Nordberg ML, Evertson J (2004). Monitoring change in mountainous dry-heath vegetation at a regional scale using multitemporal Landsat TM data. Ambio 32 (8): 502-509. [online] URL: http://www.ncbi.nlm.nih.gov/pubmed/15049346 Nordberg ML, Evertson J (2005). Vegetation index differencing and linear regression for change detection in a Swedish mountain range using Landsat $\mathrm{TM}^{\circledR}$ and ETM $+{ }^{\circledR}$ imagery. Land Degradation and Development 16 (2): 139-149. doi: 10.1002/ldr.660

Over M, Schöttker B, Braun M, Menz G (2003). 
Relative radiometric normalisation of multitemporal Landsat data - a comparison of different approaches. In: Proceedings of the Symposium "IGARSS 03: Geoscience and Remote Sensing". Toulouse (France) 21-25 July 2003. IEEE International 6: 3623-3625. - doi: 10.1109/IGARSS 2003.1294874

Penman J, Gytarsky M, Hiraushi T, Krug T, Kruger D, Pipatti R, Buendia L, Miwa K, Ngara T, Tanabe K, Wagner F (2003). Good practice guidance for land use, land use change and forestry. Chapter 3: Annex 3A.1 biomass default tables for section 3.2 forest land good practice guidance for land use, land-use change and forestry. The Institute for Global Enviromental Strategies for the IPCC and the Intergovernmental Panel on Climate Change, Hayama, Kanagawa, Japan, pp. 21.

Petit C, Scudder T, Lambin E (2001). Quantifying processes of land-cover change by remote sensing: resettlement and rapid land-cover changes in south-eastern Zambia. International Journal of Remote Sensing 22:3435-3456. - doi: 10.1080/ 01431160010006881

Phuaa MH, Tsuyuki S, Furuya N, Lee JS (2008). Detecting deforestation with a spectral change detection approach using multitemporal Landsat data: a case study of Kinabalu Park,Sabah, Malaysia. Journal of Environmental Management 88: 784-795. - doi: 10.1016/j.jenvman. 2007.04.011

Pielke RA (2005). Land use and climate change. Science 310: 1625-1626. - doi: 10.1126/science. 1120529

Piussi P (2005). Woodland recolonisation and postagricultural development in Italy. In: "Mountain ecosystems" (Broll G, Keplin B eds). Springer, Berlin, Heidelberg, Germany, pp. 237-251.

Podeh SS, Oladi J, Pormajidian MR, Zadeh MM (2009). Forest change detection in the north of Iran using TM/ETM+ imagery. Asian Journal of Applied Sciences 2:464-474. - doi: 10.3923/aja ps.2009.464.474

Pu R, Gong P, Tian Y, Miao X, Carruthers RI, Anderson GL (2008). Invasive species change detection using artificial neural networks and CASI hyperspectral imagery. Environmental Monitoring and Assessment 140 (1-3): 15-32. - doi: 10.1007/s10661-007-9843-7

Richards JA, Xiuping J (2006). Remote sensing digital image analysis: an introduction $\left(4^{\text {th }} \mathrm{edn}\right)$. Springer Birkhäuser, Basel, Switzerland.

Roy DP, Borak JS, Devadiga S, Wolfe RE, Zheng M, Descloitres J (2002). The MODIS Land product quality assessment approach. Remote Sensing of Environment 83 (1-2): 62-76. - doi: 10.1016/S0034-4257(02)00087-1

Sabins F (1997). Remote sensing: principles and interpretation ( $3^{\text {rd }}$ edn). Waveland Press Inc, Illinois, USA, pp. 494

Sader SA, Bertrand M, Wilson EH (2003). Satellite change detection of forest harvest patterns on an Industrial forest landscape. Forest Science 49 (3): 341-353.

Sarp G (2012). Determination of vegetation change using thematic mapper imagery in AfginElbistan lignite basin; SE Turkey. Procedia Technology 1: 407-411. - doi: 10.1016/j.protcy. 2012.02.092

Schroeder TA, Cohen WB, Song C, Canty MJ, Yang Z (2006). Radiometric correction of multi-temporal Landsat data for characterization of early successional forest patterns in western Oregon. Remote Sensing of Environment 103: 1626. - doi: 10.1016/j.rse.2006.03.008

Schowengerdt RA (1997). Remote sensing: models and methods for image processing ( $2^{\text {nd }}$ edn). Academic Press, San Diego, CA, USA. [ISBN 0126289816]

Sepehry A, Liu G (2006). Flood Induced land cover change detection using multitemporal ETM+ imagery. In: Proceedings of the " 2 nd Workshop of the EARseL SIG on Land Use and Land Cover: Application and Development" (Braun M ed). Center for Remote Sensing of Land Surfaces, European Association of Remote Sensing Laboratories and Universität Bonn, Bonn, Germany, pp. 399-406.

Setiawan Y, Yoshino K (2012). Change detection in land-use and land-cover dynamics at a regional scale from MODIS time-series imagery. ISPRS Annals of Photogrammetry, Remote Sensing and the Spatial Information Sciences I-7: 243-248. - doi: 10.5194/isprsannals-I-7-243-201

Short NM (1982). The Landsat tutorial workbook. Basics of satellite remote sensing. NASA Reference Pub. 1078, Superintendent of Documents, US Government Printing Office, Washington, DC, USA, pp. 553.

Shoshany M (2000). Satellite remote sensing of natural Mediterranean vegetation: a review within an ecological context. Progress in Physical Geography 24: 153-178.

Simoniello T, Carone MT, Grippa A, Liberti M, Coppola R, Macchiato M (2008). Inter-calibration of Landsat-TM/ETM scenes in heterogeneous areas. Geophysical Research Abstracts 10: EGU2008-A-11986. [online] URL: http://meetings.copernicus.org/www.cosis.net/abstracts/EG U2008/11986/EGU2008-A-11986-1.pdf

Sinch A (1986). Change detection in the tropical forest environment of northeastern India using Landsat. In: "Remote Sensing and Tropical Land Management" (Eden MJ, Parry JT eds). John Wiley and Sons, London, UK, pp. 237-254.

Singh A (1989). Digital change detection techniques using remotely-sensed data. International Journal of Remote Sensing 10: 989-1003. - doi: 10.1080/01431168908903939

Song C, Woodcock CE, Seto KC, Lenney MP, Macomber SA (2001). Classification and change detection using Landsat TM data: when and how to correct atmospheric effect. Remote Sensing of
Environment 75: 230-244. - doi: 10.1016/S00344257(00)00169-3

Story M, Congalton RG (1986). Accuracy assessment: a user's perspective. Photogrammetric Engineering and Remote Sensing 52 (3): 397-399.

Tucker CJ (1979). Red and photographic infrared linear combinations for monitoring vegetation. Remote Sensing of Environment 8: 127-150. doi: 10.1016/0034-4257(79)90013-0

Turner BL, Lambin EF, Reenberg A (2007). The emergence of land change science for global environmental change and sustainability. Proceedings of the National Academy of Sciences USA 104 (52): 20666-20671. - doi: 10.1073/pnas.07 04119104

Verbesselt J, Hyndman R, Newnham G, Culvenor D (2010). Detecting trend and seasonal changes in satellite image time series. Remote Sensing of Environment 114: 106-115. - doi: 10.1016/j.rse. 2009.08.014

Wallace J, Behn G, Furb S (2006). Vegetation condition assessment and monitoring from sequences of satellite imagery. Ecological Management and Restoration 7: 31-36. - doi: 10.1111/j. 1442-8903.2006.00289.x

Wang FY, Xu YJ (2010). Comparison of remote sensing change detection techniques for assessing hurricane damage to forests. Environ Monitoring and Assessment 162: 311-326. - doi: 10.1007/s10661-009-0798-8

Wilson EH, Sader SA (2002). Detection of forest harvest type using multiple dates of Landsat TM imagery. Remote Sensing of Environment 80: 385-396. - doi: 10.1016/S0034-4257(01)003182

Win RN, Suzuki R, Takeda S (2012). Remote sensing analysis of forest damage by selection logging in the Kabaung Reserved Forest, Bago Mountains, Myanmar. Journal of Forest Research 17: 121-128. - doi: 10.1007/s10310-0110276-3

Yacouba D, Guangdao H, Xingping W (2009). Assessment of land use cover changes using ndvi and dem in Puer and Simao counties, Yunnan Province, China. World Rural Observations 1 (2): 1-11.

Yang XI, Lo PC (2000). Relative radiometric normalization for change detection from multi-date satellite images. Photogrammetric Engineering and Remote Sensing 66 (8): 967-980.

Yuan D, Elvidge CD (1996). Comparison of relative radiometric normalization techniques. ISPRS Journal of Photogrammetry and Remote Sensing 51 (3): 117-126. - doi: 10.1016/09242716(96)00018-4

Yuan D, Elvidge CD, Lunetta RS (1998). Survey of multispectral methods for land cover change analysis. In: "Remote Change Detection. Environmental Monitoring Methods and Applications" (Lunetta RS, Elvidge CD eds). Ann Arbor Press, Chelsea, Michigan, USA, pp. 21-39. 